\title{
Pengaruh Investasi PMDN, PMA, dan Penyerapan Tenaga Kerja Terhadap Pertumbuhan Ekonomi dan Jumlah Penduduk Miskin Kabupaten/Kota di Provinsi Kalimantan Barat
}

\author{
Yetty Agustini* \\ Institut Agama Islam Negeri (IAIN) Pontianak \\ Erni Panca Kurniasih \\ Universitas Tanjungpura
}

\begin{abstract}
The purpose of the research is to know the influence of domestic investment, foreign investment, and the absorption of labor toward the local economic growth and the amount of people who live in poverty in regency/city in West Kalimantan. This study tested 6 (six) years data, from 2008 to 2013 using panel data in the form of time series data (2008-2013) and cross section (10 countries/ cities) in the West Kalimantan province. Data were analyzed using regression analysis via Eviews 6.0. The results of the research showed that: 1) Domestic Investment influnces positively and significant toward the growth of local economic in regency/city in West Kalimantan. 2) Foreign Investment influences positively and significant toward the growth of local economic in regency/city in West Kalimantan. 3) The Absorption of labor influences positively and is significant toward the amount of local economic growth in regency/city in West Kalimantan. 4) Economic growth influences negatively and significant toward the amount of people who live in poverty in regency/city in West Kalimantan.
\end{abstract}

Keywords : domestic investment, foreign investment, labor absorption, economic growth, the amount of people who live in poverty

\section{PENDAHULUAN}

Pembangunan daerah dimaksudkan untuk mendorong, memberdayakan masyarakat, menumbuhkan prakarsa serta meningkatkan partisipasi masyarakat dalam rangka membangun daerahnya, dan meningkatkan kesejahteraan masyarakat. Pembangunan yang dilaksanakan daerah meliputi berbagai bidang, salah satunya pembangunan ekonomi. Arsyad (1999) berpendapat bahwa pembangunan ekonomi daerah adalah suatu proses dimana pemerintah daerah dan masyarakat mengelola

\footnotetext{
* Korespondensi: Yetty Agustini, Institut Agama Islam Negeri (IAIN) Pontianak, email: yettytie.agustini@gmail.com.
} 
sumberdaya yang ada dan membentuk suatu pola kemitraan antara pemerintah daerah dengan sektor swasta untuk menciptakan lapangan kerja baru dan merangsang perkembangan kegiatan ekonomi (pertumbuhan ekonomi) dalam wilayah tersebut.

Penanaman Modal Asing maupun Penanaman Modal Dalam Negeri kabupaten/kota di Provinsi Kalimantan Barat mengalami fluktuasi. Penanaman Modal Asing (PMA) mengalami kenaikan setiap tahunnya dimulai pada tahun 2008 yakni sebesar 786.297,15 (juta Rp) dan terbesar pada tahun 2013 sebesar 2.697.816,72 (juta Rp). Begitu juga dengan Penanaman Modal Dalam Negeri juga mengalami kenaikan setiap tahunnya. Tahun 2008 adalah tahun paling kecil jumlah penanaman modal dalam negeri dalam kurun waktu tahun 2008-2013 yakni sebesar 5.201.254,75 (juta Rp), dan terbesar pada tahun 2013 sebesar 17.266.076,95 (juta Rp).

Pertumbuhan ekonomi sebagai indikator untuk melihat keberhasilan pembangunan dan merupakan syarat keharusan (necessary condition) bagi pengurangan tingkat kemiskinan. Adapun syarat kecukupannya ialah bahwa pertumbuhan ekonomi tersebut efektif dalam mengurangi tingkat kemiskinan. Dalam kurun waktu enam tahun terakhir yaitu 2008 sampai tahun 2013 jumlah penduduk miskin mengalami penurunan namun tidak terlalu signifikan jika dilihat dari pertumbuhan ekonomi yang terus meningkat. Secara agregat, jumlah angkatan kerja menurut kabupaten/kota di Provinsi Kalimantan Barat dari tahun 2008-2013 terus mengalami peningkatan.

Jumlah penduduk yang tinggi akan menyebabkan tingginya jumlah pengangguran dan jumlah kemiskinan menjadi meningkat apabila tidak didukung dengan penyediaan lapangan kerja yang memadai bagi penduduk usia kerja. Berdasarkan data jumlah penduduk tahun 2013, Provinsi Kalimantan Barat merupakan provinsi dengan jumlah penduduk terbanyak dibandingkan dengan dua provinsi lainnya yaitu mencapai sekitar lebih dari 4,6 juta jiwa, diikuti oleh Provinsi Kalimantan Timur dengan jumlah penduduk sebanyak lebih dari 3,8 juta jiwa, dan Kalimantan Selatan dengan jumlah penduduk sebanyak lebih dari 3,8 juta jiwa.

Apabila jumlah lapangan kerja semakin banyak akan diikuti dengan banyaknya jumlah tenaga kerja yang terserap, maka akan berpotensi menurunkan jumlah penduduk miskin yang berakibat pada meningkatnya kesejahteraan masyarakat. Angkatan kerja yang bekerja selama periode waktu 2008 sampai dengan 2013 terus mengalami peningkatan dengan rata-rata penyerapan tenaga kerja sebesar 150.798,48 jiwa per tahun. Menurut kabupaten/kota di Provinsi Kalimantan Barat, Kabupaten Sambas mampu menyerap tenaga kerja terbesar dibanding kabupaten/kota lainnya yaitu rata-rata sebesar 252.693,29 jiwa per tahun selama periode waktu 2008-2013, diikuti Kota Pontianak dengan penyerapan tenaga kerja rata-rata sebanyak 226.298,14 jiwa per tahun dan Kabupaten Kubu Raya dengan penyerapan tenaga kerja sebanyak 221.024,14 jiwa per tahun. 
Secara teoritis, tingkat investasi dikatakan berkorelasi positif dengan tingkat pertumbuhan ekonomi. Secara sederhana, tingkat investasi yang tinggi akan meningkatkan kapasitas produksi, yang pada akhirnya berujung pada peningkatan pendapatan masyarakat. Akan tetapi fakta yang terjadi di Provinsi Kalimantan Barat menunjukkan bahwa pada saat investasi mengalami pertumbuhan yang tinggi, belum mampu mendorong meningkatnya pertumbuhan ekonomi.

Laju pertumbuhan ekonomi kabupaten/kota di Provinsi Kalimantan Barat selama 6 tahun terakhir berfluktuasi. Kenaikan dan penurunan tersebut secara teori dapat dipengaruhi oleh investasi dan tenaga kerja. Investasi PMDN dan PMA di Provinsi Kalimantan Barat setiap tahunnya terus mengalami peningkatan. Perkembangan investasi kabupaten/kota di Provinsi Kalimantan Barat selama periode 2008-2013 berfluktuasi (baik PMDN maupun PMA). Peran investasi belum terlihat dalam mendukung pertumbuhan ekonomi. Pada saat investasi PMDN dan PMA sama-sama menunjukkan peningkatan, tetapi belum diiringi oleh pertumbuhan ekonomi yang tinggi pula.

Berdasarkan data yang ada diketahui bahwa perkembangan investasi di Provinsi Kalimantan Barat selama 6 tahun terakhir terlihat belum optimal, dimana investasi menunjukkan peningkatan yang cukup tinggi tetapi belum bisa mendorong pertumbuhan ekonomi. Pada saat investasi menunjukkan penurunan, tidak menyebabkan pertumbuhan ekonomi menjadi rendah. Fakta ini memberikan informasi yang menarik, apakah investasi berpengaruh positif terhadap pertumbuhan ekonomi kabupaten/kota di Provinsi Kalimantan Barat.

Menarik untuk dicermati, beberapa kabupaten/kota dengan nilai rata-rata investasi yang lebih tinggi dibanding daerah lainnya justru memiliki jumlah penduduk miskin yang tinggi. Hal ini terjadi pada Kabupaten Sambas, Kabupaten Ketapang, Kabupaten Kapuas Hulu dan Kabupaten Landak. Bahkan untuk Kabupaten Ketapang, memiliki rata-rata pertumbuhan ekonomi tertinggi dibanding kabupaten/kota lainnya di Provinsi Kalimantan Barat. Tenaga kerja juga dipandang sebagai salah satu faktor yang mempengaruhi output suatu daerah. Angkatan kerja yang besar akan terbentuk dari jumlah penduduk yang besar. Dari jumlah penduduk usia produktif yang besar maka akan mampu meningkatkan jumlah angkatan kerja yang tersedia dan pada akhirnya akan mampu mengingkatkan produksi output suatu daerah.

Tujuan yang ingin dicapai dalam penelitian ini adalah: (1) Menganalisis pengaruh investasi PMDN terhadap pertumbuhan ekonomi kabupaten/kota di Provinsi Kalimantan Barat. (2) Pengaruh investasi PMA terhadap pertumbuhan ekonomi kabupaten/kota di Provinsi Kalimantan Barat. (3) Pengaruh penyerapan tenaga kerja terhadap pertumbuhan ekonomi kabupaten/kota di Provinsi Kalimantan Barat. (4) Pengaruh pertumbuhan ekonomi terhadap jumlah penduduk miskin kabupaten/kota di Provinsi Kalimantan Barat. Penelitian ini diharapkan memberikan manfaat sebagai bahan kajian dan evaluasi bagi pengambil kebijakan dan mampu memberikan informasi yang berguna dalam memahami pengaruh investasi PMDN, PMA, dan penyerapan 
tenaga kerja terhadap pertumbuhan ekonomi dan jumlah penduduk miskin sehingga dapat diketahui faktor-faktor yang perlu dipacu untuk pengentasan kemiskinan.

\section{KAJIAN LITERATUR}

Kemiskinan menurut Kuncoro (2006) adalah ketidakmampuan untuk memenuhi standar hidup minimum. Kemiskinan berbeda dengan ketimpangan distribusi pendapatan (inequality). Kemiskinan berkaitan erat dengan standar hidup yang absolut dari bagian masyarakat tertentu, sedangkan ketimpangan mengacu pada standar hidup relatif dari seluruh masyarakat. Pada tingkat ketimpangan yang maksimum, kekayaan dimiliki oleh satu orang saja, dan tingkat kemiskinan sangat tinggi. Permasalahan standar hidup yang rendah berkaitan pula dengan jumlah pendapatan yang sedikit (kemiskinan), perumahan yang kurang layak, kesehatan dan pelayanan kesehatan yang buruk, tingkat pendidikan masyarakat yang rendah sehingga berakibat pada rendahnya sumber daya manusia dan banyaknya pengangguran. Tingkat standar hidup dalam suatu negara bisa diukur dari beberapa indikator antara lain Gross National Product (GNP) per kapita, pertumbuhan relatif nasional dan pendapatan per kapita, distribusi pendapatan nasional, tingkat kemiskinan, dan tingkat kesejahteraan masyarakat.

Hoffman dalam Jhingan (2008) melukiskan dengan jelas gambar suatu negara yang terbelakang dalam ungkapan sebagai berikut, "Setiap orang dapat memahami suatu negara terbelakang apabila ia melihatnya. Ia adalah suatu negara yang ditandai oleh kemiskinan, kota yang dipadati oleh pengemis dan penduduk desa yang sudah mencari nafkah di kampung halamannya sendiri. Ia adalah suatu negara yang jarang memiliki industri, seringkali dengan persediaan tenaga dan listrik yang tidak memadai. Negara seperti itu biasanya tidak memiliki jalan raya dan jalan kereta api yang cukup, pemerintah belum dapat memberikan pelayanan yang memadai, dan komunikasi yang ada biasanya sangat buruk. Rumah sakit dan lembaga pendidikan tinggi sangat sedikit. Sebagian besar penduduk buta huruf.

Disamping sebagian besar rakyat yang miskin, ada pula beberapa daerah yang makmur dengan segelintir penduduk yang hidup dalam kemewahan. Sistem perbankan jelek, pinjaman dalam jumlah kecil terpaksa diperoleh dari pemilik uang yang tidak lebih baik daripada seorang lintah darat. Diantara ciri menonjol negara terbelakang ialah ekspornya ke negara lain terdiri dari bahan mentah, hasil tambang, atau buah-buahan, atau beberapa bahan makanan dan mungkin ditambah dengan sedikit hasil kerajian tangan yang halus. Penanaman atau pengusahaan ekspor bahan mentah sering berada ditangan perusahaan asing."

Kemiskinan mempunyai pengertian yang luas dan memang tidak mudah untuk mengukurnya. Oleh karena itu, para ahli ekonomi merancang teknik tertentu yang memberikan gambaran resmi tentang kemiskinan. Menurut Kuncoro (2006), batas garis kemiskinan yang digunakan setiap negara ternyata berbeda-beda. Ini disebabkan karena 
adanya perbedaan lokasi dan standar kebutuhan hidup. Untuk mengukur kemiskinan, Indonesia melalui BPS menggunakan batas miskin dari besarnya rupiah yang dibelanjakan per kapita sebulan untuk memenuhi kebutuhan minimum makanan dan bukan makanan. Untuk kebutuhan minimum makanan, digunakan patokan 2.100 kalori per hari. Sedangkan pengeluaran kebutuhan minimum bukan makanan meliputi pengeluaran untuk perumahan, sandang, serta aneka barang dan jasa. Dengan kata lain, BPS menggunakan dua macam pendekatan, yaitu: pendekatan kebutuhan dasar (Basic Needs Approach) dan pendekatan HDI (Head Count Index).

Dalam metode BPS, kemiskinan dikonseptualisasikan sebagai ketidakmampuan untuk memenuhi kebutuhan dasar. Sedangkan Head Count Index merupakan ukuran yang menggunakan kemiskinan absolut. Jumlah penduduk miskin adalah jumlah penduduk yang berada dibawah suatu batas yang disebut batas garis kemiskinan, yang merupakan nilai rupiah dari kebutuhan minimum makanan dan non-makanan. Dengan demikian, garis kemiskinan (GK) terdiri dari dua komponen, yaitu garis kemiskinan makanan (GKM) dan garis kemiskinan non-makanan (GKNM).

Mengutip logika berpikir yang dikemukakan Nurske dalam Kuncoro (2006), adanya keterbelakangan, ketidaksempurnaan pasar, dan kurangnya modal menyebabkan rendahnya produktivitas. Rendahnya produktivitas mengakibatkan rendahnya pendapatan yang mereka terima. Rendahnya pendapatan akan berimplikasi pada rendahnya tabungan dan investasi. Rendahnya investasi berakibat pada keterbelakangan, dan seterusnya. Ekonom pembangunan Nurske tersebut di tahun 1953 mengatakan, "a poor country is poor because it is poor" (negara miskin itu miskin karena dia miskin).

Pertumbuhan ekonomi menurut Simon Kuznet (Jhingan, 2008) adalah kemampuan suatu negara untuk menyediakan semakin banyaknya jenis barang-barang ekonomi kepada penduduknya, kemampuan ini tumbuh sesuai dengan kemajuan ekonomi, penyesuaian kelembagaan dan ideologis yang diperlukan. Definisi di atas memiliki tiga komponen pengertian: Pertama, pertumbuhan ekonomi suatu bangsa terlihat dari meningkatnya secara terus menerus persediaan barang. Kedua, teknologi maju merupakan faktor utama dalam pertumbuhan ekonomi yang menentukan derajat pertumbuhan dalam penyediaan aneka macam barang kepada penduduk. Ketiga, penggunaan teknologi secara luas dan efisien memerlukan adanya penyesuaian di bidang kelembangaan dan ideologi sehingga inovasi yang dihasilkan oleh ilmu pengetahuan umat manusia dapat dimanfaatkan secara tepat.

Teori Harrod-Domar mengingatkan kita bahwa sebagai akibat investasi yang dilakukan tersebut pada masa berikutnya kapasitas barang-barang modal dalam perekonomian akan bertambah (Sukirno, 2010). Menurut Harrod-Domar (Sukirno, 2010) pada hakekatnya investasi berusaha untuk menunjukan syarat yang diperlukan agar terjadi pertumbuhan yang mantap atau Steady Growth yang dapat didefinisikan sebagai pertumbuhan yang akan selalu menciptakan penggunaan sepenuhnya alat-alat modal yang akan selalu berlaku dalam perekonomian. Pokok penjelasan dari teori tersebut 
bahwa penanaman modal yang dilakukan masyarakat dalam waktu tertentu digunakan untuk dua tujuan. Pertama untuk mengganti alat-alat modal yang tidak dapat digunakan lagi. Kedua untuk memperbesar jumlah alat-alat modal yang tersedia dalam masyarakat.

Investasi dapat diartikan sebagai pengeluaran atau pengeluaran penanampenanam modal atau perusahaan untuk membeli barang-barang modal dan perlengkapanperlengkapan produksi untuk menambah kemampuan memproduksi barang-barang dan jasa-jasa yang tersedia dalam perekonomian (Sukirno, 2010). Pertambahan jumlah barang modal ini memungkinkan perekonomian tersebut menghasilkan lebih banyak barang dan jasa di masa yang akan datang. Tenaga kerja adalah modal bagi bergeraknya roda pembangunan. Jumlah dan komposisi tenaga kerja akan terus mengalami perubahan seiring dengan berlangsungnya proses demografi. Dalam kegiatan proses produksi, tenaga kerja merupakan faktor yang terpenting karena manusia yang menggerakkan semua sarana produksi seperti bahan mentah, air, dan sebagainya.

Menurut BPS (2013), yang dimaksud dengan tenaga kerja (manpower) adalah setiap orang/penduduk usia kerja (15 tahun keatas) yang mampu melakukan pekerjaan guna menghasilkan barang dan/atau jasa baik untuk memenuhi kebutuhan sendiri ataupun kebutuhan masyarakat. Tenaga kerja (manpower) dibagi pula ke dalam dua kelompok yaitu angkatan kerja (laborforce) dan bukan angkatan kerja. Yang termasuk angkatan kerja ialah tenaga kerja atau penduduk dalam usia kerja, atau yang mempunyai pekerjaan namun untuk sementara sedang tidak bekerja, dan yang sedang mencari pekerjaan. Sedangkan yang termasuk bukan angkatan kerja adalah tenaga kerja atau penduduk dalam usia kerja yang tidak bekerja, tidak mempunyai pekerjaan dan sedang tidak mencari pekerjaan (Rahardja dan Manurung, 2005).

Ketimpangan pembangunan ekonomi mendapat banyak perhatian peneliti. Misalnya menurut Klassen dalam Agussalim (2009) pertumbuhan hanya dapat disebut pro poor jika tingkat pertumbuhan orang miskin berada diatas tingkat pertumbuhan pendapatan rata-rata. Dengan kata lain pertumbuhan relatif bisa berpengaruh terhadap orang miskin dalam artian pendapatan mereka relatif meningkat dibandingkan dengan kelompok pendapatan masyarakat lainya. Hal tersebut senada namun dalam konteks yang lebih jelas dengan apa yang dikatakan oleh Ravalioon (1997), Son dan Kakwani (2003) dan Bourgoignon (2004) bahwa dampak pertumbuhan ekonomi terhadap penurunan angka kemiskinan hanya terjadi jika ketimpangan relatif tinggi. Artinya bagi negara yang memiliki tingkat ketimpangan sedang apalagi rendah dampak pertumbuhan terhadap kemiskinan relatif tidak signifikan.

\section{METODA PENELITIAN}

Penelitian ini berbasis pada penelitian eksplanatory. Menurut Hermawan (2009), "Explanatory Research merupakan penelitian yang menjelaskan hubungan kausal antara variabel-variabel melalui pengujian hipotesis". Metode explanatory research dapat 
dikatakan sebagai penelitian untuk menguji hipotesis antara variabel yang satu dengan variabel yang lainnya. Data dalam penelitian ini merupakan data sekunder yang berasal dari BPS, merupakan pooling data yaitu gabungan antara time series (tahun 2008-2013) selama 6 (enam) tahun dengan cross section 10 (sepuluh) kabupaten/kota di Provinsi Kalimantan Barat yang menghasilkan 60 observasi.

Penelitian ini menguji dan menjelaskan pengaruh investasi PMDN, Investasi PMA, dan penyerapan tenaga kerja terhadap pertumbuhan ekonomi dan jumlah penduduk miskin, dianalisis dengan teknkik random effect melalui bantuan software $E$ Views 6.0.

\section{HASIL PENELITIAN DAN PEMBAHASAN}

\section{Pertumbuhan Ekonomi}

Pertumbuhan ekonomi merupakan target yang ingin dicapai oleh perekonomian dalam jangka panjang, dan semaksimal mungkin konsisten dengan pertumbuhan ekonomi jangka pendek. Pertumbuhan ekonomi dapat menerangkan dan sekaligus dapat mengukur prestasi perkembangan suatu perekonomian. Pertumbuhan ekonomi berarti perkembangan kegiatan dalam perekonomian yang menyebabkan barang dan jasa yang diproduksi oleh masyarakat bertambah, sehingga kemakmuran masyarakat meningkat (Sukirno, 2010).

Tabel 1 menggambarkan laju pertumbuhan ekonomi daerah kabupaten/kota di Provinsi Kalimantan Barat selama tahun 2008 sampai tahun 2013, dengan laju pertumbuhan ekonomi rata-rata 4,65 persen per tahun. Laju pertumbuhan ekonomi terbesar adalah pada Kabupaten Ketapang yaitu sebesar 6,25 persen per tahun, sedangkan rata-rata pertumbuhan ekonomi terendah di Kabupaten Pontianak yaitu 4,18 persen per tahun. 
Tabel 1

Pertumbuhan Ekonomi Menurut Kabupaten/Kota di Provinsi Kalimantan Barat, Tahun 2008-2013 (\%)

\begin{tabular}{|c|c|c|c|c|c|c|c|}
\hline Kabupaten/Kota & 2008 & 2009 & 2010 & 2011 & 2012 & 2013 & Rata2 \\
\hline Kab Sambas & 5.51 & 5.43 & 5.79 & 5.80 & 5.88 & 5.99 & 5.68 \\
\hline Kab Bengkayang & 5.57 & 4.50 & 4.63 & 5.65 & 5.74 & 6.04 & 5.46 \\
\hline Kab Landak & 4.29 & 4.71 & 5.13 & 6.90 & 6.01 & 6.21 & 5.48 \\
\hline Kab Pontianak & 5.90 & 1.32 & 2.13 & 4.78 & 3.04 & 5.08 & 4.18 \\
\hline Kab Sanggau & 3.49 & 4.95 & 4.15 & 4.61 & 5.92 & 6.04 & 4.95 \\
\hline Kab Ketapang & 7.14 & -1.22 & 7.51 & 7.98 & 5.01 & 6.97 & 6.25 \\
\hline Kab Sintang & 4.70 & 5.38 & 5.19 & 5.49 & 5.78 & 6.34 & 5.43 \\
\hline Kab Kapuas Hulu & 3.55 & 3.70 & 4.44 & 4.56 & 5.60 & 6.01 & 4.47 \\
\hline Kab Sekadau & 5.76 & 5.35 & 5.85 & 5.73 & 5.95 & 6.71 & 6.14 \\
\hline Kab Melawi & 5.11 & 4.27 & 5.75 & 6.14 & 6.48 & 6.73 & 5.70 \\
\hline Kab. Kayong Utara & 5.84 & 2.78 & 5.92 & 5.93 & 6.01 & 6.00 & 5.17 \\
\hline Kab. Kubu Raya & 5.02 & 5.87 & 6.23 & 6.51 & 6.69 & 6.79 & 5.97 \\
\hline Kota Pontianak & 5.34 & 5.35 & 5.39 & 5.88 & 6.07 & 6.91 & 5.77 \\
\hline Kota Singkawang & 4.90 & 4.88 & 5.54 & 6.46 & 6.16 & 6.36 & 5.57 \\
\hline$\underline{\text { Kalimantan Barat }}$ & 5.15 & 4.09 & 5.33 & 5.85 & 5.79 & 6.30 & 4.65 \\
\hline
\end{tabular}

Sumber: BPS Provinsi Kalimantan Barat, berbagai tahun

\section{Investasi}

Laju pertumbuhan ekonomi sebagai tolok ukur pertumbuhan suatu ekonomi regional juga tidak lepas dari peran adanya investasi. Untuk mendorong pembangunan ekonomi tersebut, salah satu usaha yang dapat dilakukan oleh pemerintah Provinsi Kalimantan Barat adalah dengan mendorong para investor baik investor lokal maupun investor asing untuk melakukan investasi di Provinsi Kalimantan Barat, dan diharapkan dapat memberikan peningkatan pendapatan bagi daerah Provinsi Kalimantan Barat. 
Tabel 2

Penanaman Modal Dalam Negeri Kabupaten/Kota di Provinsi Kalimantan Barat Tahun 2008-2013 (Juta Rupiah)

\begin{tabular}{|c|c|c|c|c|c|c|}
\hline Kabupaten/Kota & 2008 & 2009 & 2010 & 2011 & 2012 & 2013 \\
\hline Kab Sambas & 5992.00 & 15992.00 & 176431.46 & 215960.87 & 350249.94 & 479720 \\
\hline Kab Bengkayang & 29454.00 & 29454.00 & 106991.30 & 106991.30 & 370442.41 & 370442 \\
\hline Kab Landak & 6130.79 & 6130.79 & 6130.79 & 6130.79 & 6130.79 & 6131 \\
\hline Kab Pontianak & 935016.48 & 987724.74 & 1154024.97 & 1214209.50 & 1190496.96 & 1478647 \\
\hline Kab Sanggau & 1501283.37 & 1929033.95 & 2010045.73 & 2233563.93 & 2253210.93 & 3201230 \\
\hline Kab Ketapang & 925053.83 & 1097660.91 & 1701380.03 & 2313365.71 & 2899871.23 & 3394454 \\
\hline Kab Sintang & 1431113.00 & 1539241.57 & 1607042.57 & 1671116.99 & 1781726.99 & 2009905 \\
\hline Kab Kapuas Hulu & 197446.00 & 536674.57 & 1424480.03 & 2037428.40 & 2993519.38 & 3679436 \\
\hline Kab Sekadau & - & - & - & - & - & 422654 \\
\hline Kab Melawi & 930.48 & 930.48 & 930.48 & 930.48 & 930.48 & 930 \\
\hline Kab.Kayong Utara & - & - & - & - & - & - \\
\hline Kab. Kubu Raya & - & - & - & 10668.47 & 744577.60 & 1603827 \\
\hline Kota Pontianak & 168834.80 & 196336.60 & 194284.60 & 194302.99 & 563577.60 & 563924 \\
\hline Kota Singkawang & - & - & - & - & 563924.34 & 54776 \\
\hline Kalimantan Barat & 5201254.75 & 6339179.61 & 8381741.96 & 10004669.43 & 13177576.05 & 17266076.95 \\
\hline
\end{tabular}

Sumber: BPS Provinsi Kalimantan Barat (Kalbar Dalam Angka 2007-2014)

Tabel 3

Penanaman Modal Asing Kabupaten/Kota di Provinsi Kalimantan Barat Tahun 2008-2013 (Ribu US \$)

\begin{tabular}{|c|c|c|c|c|c|c|}
\hline Kabupaten/Kota & 2008 & 2009 & 2010 & 2011 & 2012 & 2013 \\
\hline Kab Sambas & 40083.63 & 40083.63 & 52365.51 & 53853.88 & 116183.12 & 186838.54 \\
\hline Kab Bengkayang & 10360.43 & 10360.43 & 10480.43 & 11361.97 & 11361.97 & 11707.84 \\
\hline Kab Landak & 126038.84 & 142823.91 & 162975.95 & 185614.13 & 202760.47 & 217722.07 \\
\hline Kab Pontianak & 60682.05 & 65245.88 & 60644.15 & 62144.15 & 31963.68 & 181963.68 \\
\hline Kab Sanggau & 256899.02 & 256899.02 & 343088.83 & 458102.67 & 660720.67 & 735862.88 \\
\hline Kab Ketapang & 228062.81 & 317308.19 & 322056.06 & 389459.24 & 540341.49 & 649818.05 \\
\hline Kab Sintang & 3819.12 & 38140.30 & 38140.30 & 38140.30 & 60696.57 & 81756.07 \\
\hline Kab Kapuas Hulu & 500.00 & 500.00 & 1480.19 & 9753.10 & 33813.06 & 33813.06 \\
\hline Kab Sekadau & 37040.27 & 37040.37 & 37092.48 & 41308.61 & 124250.66 & 168845.34 \\
\hline Kab Melawi & 354.40 & 3554.90 & 3554.90 & 3554.90 & 42819.09 & 42819.09 \\
\hline Kab. Kayong Utara & - & - & - & - & - & - \\
\hline Kab. Kubu Raya & - & 7130.00 & 65757.63 & 111898.55 & 170390.34 & 296911.24 \\
\hline Kota Pontianak & 22456.58 & 25091.34 & 25112.72 & 25112.72 & 71951.69 & 89758.86 \\
\hline Kota Singkawang & - & - & - & - & - & - \\
\hline Kalimantan Barat & 786297.15 & 944177.97 & 1122749.15 & 1390304.22 & 2067252.81 & 2697816.72 \\
\hline
\end{tabular}

Sumber: BPS Provinsi Kalimantan Barat (Kalbar Dalam Angka 2007-2014) 
Berdasarkan Tabel 2 dan 3, baik Penanaman Modal Asing maupun Penanaman Modal Dalam Negeri kabupaten/kota di Provinsi Kalimantan Barat mengalami fluktuasi. Penanaman Modal Asing (PMA) mengalami kenaikan setiap tahunnya dimulai pada tahun 2008 yakni sebesar 786.297,15 (juta Rp) dan terbesar pada tahun 2013 sebesar 2.697.816,72 (juta Rp). Begitu juga dengan Penanaman Modal Dalam Negeri juga mengalami kenaikan setiap tahunnya, tahun 2008 adalah tahun paling kecil jumlah penanaman modal dalam negeri dalam kurun waktu tahun 2008-2013 yakni sebesar 5.201.254,75 (juta Rp), dan terbesar pada tahun 2013 sebesar 17.266.076,95 (juta Rp).

\section{Jumlah Penduduk Miskin}

Kemiskinan menurut BPS (2013) adalah ketidakmampuan memenuhi standar minimum kebutuhan dasar yang meliputi kebutuhan makan maupun non makan.

Tabel 4

Jumlah Penduduk Miskin Kabupaten/Kota di Provinsi Kalimantan Barat Tahun 2008-2013 (Jiwa)

\begin{tabular}{|c|c|c|c|c|c|c|}
\hline & 2008 & 2009 & 2010 & 2011 & 2012 & 2013 \\
\hline Kab Sambas & 61500 & 53800 & 50036 & 46980 & 46980 & 51200 \\
\hline Kab Bengkayang & 21100 & 17900 & 16813 & 15785 & 15785 & 18400 \\
\hline Kab Landak & 66000 & 55800 & 46499 & 43691 & 43691 & 49500 \\
\hline Kab Pontianak *) & 15752 & 13100 & 15001 & 14094 & 14094 & 15600 \\
\hline Kab Sanggau & 26500 & 19900 & 20505 & 19262 & 19262 & 20400 \\
\hline Kab Ketapang & 67700 & 59600 & 58494 & 54966 & 54966 & 58800 \\
\hline Kab Sintang & 54100 & 46900 & 35544 & 33356 & 33356 & 39000 \\
\hline Kab Kapuas Hulu & 27300 & 24100 & 25329 & 23772 & 23772 & 26400 \\
\hline Kab Sekadau & 14800 & 12600 & 12299 & 11557 & 11557 & 13200 \\
\hline Kab Melawi & 27100 & 23500 & 24759 & 23302 & 23302 & 26000 \\
\hline Kab. Kayong Utara & 14400 & 12500 & 11190 & 10523 & 10523 & 11100 \\
\hline Kab. Kubu Raya *) & 38748 & 37100 & 35893 & 33731 & 33731 & 32100 \\
\hline Kota Pontianak & 52800 & 36600 & 36625 & 34389 & 34389 & 32800 \\
\hline Kota Singkawang & 15100 & 12000 & 11420 & 10711 & 10711 & 13000 \\
\hline Kalimantan Barat & 502900 & 425400 & 400407 & 376119 & 376119 & 407300 \\
\hline
\end{tabular}

Sumber: BPS Provinsi Kalimantan Barat (Kalbar Dalam Angka 2007-2014)

Data di atas menunjukkan bahwa dalam kurun waktu enam tahun terakhir yaitu 2008 sampai tahun 2013 jumlah penduduk miskin mengalami penurunan namun tidak terlalu signifikan jika dilihat dari pertumbuhan ekonomi yang terus meningkat. 


\section{Pengujian Regresi Tahap Pertama}

Tahap pengujian pertama dilakukan pada variabel Penanaman Modal Dalam Negeri, Penanaman Modal Asing, dan Penyerapan Tenaga Kerja menurut kabupaten/kota di Provinsi Kalimantan Barat tahun 2008-2013.

Tabel 5

Hasil Pengujian Regresi Tahap I

\begin{tabular}{crcrr}
\hline Dependent Variable: PE? & & & & \\
\hline \hline Variable & Coefficient & Std. Error & t-Statistic & Prob. \\
\hline \hline C & -19.00902 & 16.52936 & -1.150016 & 0.2560 \\
LNPMDN? & 0.052832 & 0.048748 & 1.083784 & 0.2840 \\
LNPMA? & 0.414561 & 0.067965 & 6.099599 & 0.0000 \\
LNPTK? & 1.601599 & 1.359989 & 1.177656 & 0.2449 \\
Fixed Effects (Cross) & & & & \\
BKY--C & 1.422912 & & & \\
KABPTK--C & -1.623983 & & & \\
KH--C & 0.767300 & & & \\
KTPG--C & -0.677760 & & & \\
LDK--C & -0.064833 & & & \\
MLW--C & 2.462716 & & \\
PTK--C & 0.051879 & & \\
SBS--C & -0.394127 & & \\
SGU--C & -1.889829 & & \\
STG--C & -0.054274 & & \\
\hline \hline
\end{tabular}

Sumber: Output Eviews 16.0, tahun 2017

Berdasarkan hasil uji di atas, maka persamaan regresi tahap pertama yang diperoleh adalah:

$$
\mathrm{PE}=-19,001+0,053 \mathrm{PMDN}+0,415 \mathrm{PMA}+1,602 \mathrm{PTK}
$$

Hasil pengujian menunjukkan nilai konstanta sebesar -19,001, artinya apabila variabel PMDN, PMA, dan penyerapan Tenaga Kerja tidak mengalami perubahan, maka Pertumbuhan Ekonomi kabupaten/kota di Provinsi Kalimantan Barat sebesar -19,001 persen. Nilai koefisien masing-masing variabel akan dijelaskan sebagai berikut: 
- Koefisien regresi untuk variabel penanaman modal dalam negeri ( $\beta_{1}$ ) sebesar 0,053. Hal ini berarti bahwa jika PMDN bertambah sebesar 1 persen pertahun, maka akan meningkatkan pertumbuhan ekonomi (karena tandanya positif) sebesar 0,053 persen.

- Koefisien regresi untuk variabel penanaman modal asing $\left(\beta_{2}\right)$ sebesar 0,415. Hal ini berarti bahwa jika PMA bertambah sebesar 1 persen pertahun, maka akan meningkatkan pertumbuhan ekonomi (karena tandanya positif) sebesar 0,415 persen.

- Koefisien regresi untuk variabel Penyerapan Tenaga Kerja ( $\left.\beta_{3}\right)$ sebesar 1,602. Hal ini berarti bahwa jika Penyerapan Tenaga Kerja bertambah sebesar 1 persen pertahun, maka akan meningkatkan pertumbuhan ekonomi (karena tandanya positif) sebesar 1,602 persen.

\section{Uji Signifikansi Simultan (Uji F)}

Nilai probabilitas Uji F menunjukkan angka 0,00000 dengan signifikansi $\alpha=$ 0,01. Hal ini menunjukkan bahwa Penanaman Modal Dalam Negeri (PMDN), Penanaman Modal Asing (PMA), dan Penyerapan Tenaga Kerja (PTK) secara bersamasama mempengaruhi Pertumbuhan Ekonomi pada kabupaten/kota di Provinsi Kalimantan Barat tahun 2008-2013.

\section{Uji Signifikansi Parameter Individual (Uji t)}

Berdasarkan uji parsial yang dilakukan, diperoleh nilai probabilitas t-hitung sebagai berikut:

1. Penananam Modal Dalam Negeri $\left(\mathrm{X}_{1}\right)$ nilai probabilitas t-hitung sebesar 1.083784 dengan signifikansi $\alpha=0,01$, artinya Ho ditolak dan $\mathrm{H}_{1}$ diterima yaitu penanaman modal dalam negeri berpengaruh signifikan terhadap pertumbuhan ekonomi pada kabupaten/kota di Provinsi Kalimantan Barat.

2. Penyerapan Tenaga Kerja $\left(\mathrm{X}_{2}\right)$ nilai probabilitas t-hitung 0.2449 sebesar dengan signifikansi $\alpha=0,01$, artinya Ho ditolak dan $\mathrm{H}_{1}$ diterima yaitu penyerapan tenaga kerja berpengaruh signifikan terhadap pertumbuhan ekonomi pada kabupaten/kota di Provinsi Kalimantan Barat.

\section{Uji Koefisien Determinasi (Uji $\mathbf{R}^{\mathbf{2}}$ )}

Nilai Adjusted $R$-Squared menunjukkan angka 0.624252, ini berarti bahwa setelah disesuaikan penanaman modal dalam negeri dan penyerapan tenaga kerja mempengaruhi pertumbuhan ekonomi sebesar 62,43 persen, sisanya 37,57 persen dipengaruhi oleh faktor-faktor lain di luar penelitian. Faktor-faktor lain yang dapat mempengaruhi pertumbuhan ekonomi antara lain kemajuan teknologi. 


\section{Pengujian Regresi Tahap Kedua}

Pengujian tahap kedua dilakukan untuk mengetahui pengaruh estimasi Pertumbuhan Ekonomi (PE) terhadap Jumlah Penduduk Miskin (JPM) kabupaten/kota di Provinsi Kalimantan Barat Tahun 2008-2013.

Tabel 6

Hasil Pengujian Regresi Tahap II

Dependent Variable: LNJPM?

\begin{tabular}{crrrr}
\hline \hline Variable & Coefficient & Std. Error & t-Statistic & Prob. \\
\hline C & 10.74781 & 0.207251 & 51.85888 & 0.0000 \\
PEEST? & -0.051376 & 0.025585 & -2.008039 & 0.0502 \\
Fixed Effects (Cross) & & & \\
BKY--C & -0.620648 & & \\
KABPTK--C & -0.736780 & & \\
KH--C & -0.270094 & & \\
KTPG--C & 0.713809 & & \\
LDK--C & 0.511802 & & \\
MLW--C & -0.308787 & & 1.393234 \\
PTK--C & 0.215684 & & \\
SBS--C & 0.552654 & & 1.230450 \\
SGU--C & -0.321709 & & \\
STG--C & 0.264070 & & \\
\hline \hline & Effects Specification & \\
\hline \hline Cross-section fixed (dummy & variables) & & \\
\hline \hline
\end{tabular}

Sumber: Output Eviews 16.0, tahun 2017

Berdasarkan hasil uji di atas, maka persamaan regresi tahap kedua yang diperoleh sebagai berikut:

$$
\text { LnJPM }=-0,051 \hat{P E}
$$

Hasil pengujian menunjukkan nilai koefisien regresi untuk variabel Pertumbuhan Ekonomi sebesar -0,051, artinya apabila variabel Pertumbuhan Ekonomi tidak 
mengalami perubahan, maka jumlah penduduk miskin kabupaten/kota di Provinsi Kalimantan Barat adalah sebesar - 0,051 persen.

\section{Uji Signifikansi Simultan (Uji F)}

Nilai probabilitas Uji F menunjukkan angka 0,00000 dengan signifikansi $\alpha=$ 0,01 . Hal ini menunjukkan bahwa estimasi pertumbuhan ekonomi secara bersama-sama mempengaruhi jumlah penduduk miskin pada kabupaten/kota di Provinsi Kalimantan Barat tahun 2008-2013.

\section{Uji Signifikansi Parameter Individual (Uji t)}

Berdasarkan uji parsial yang dilakukan, diperoleh nilai probabilitas t-hitung sebesar -2.008039 dengan signifikansi $\alpha=0,01$, artinya Ho ditolak dan $\mathrm{H}_{1}$ diterima yaitu Pertumbuhan Ekonomi berpengaruh signifikan terhadap Jumlah Penduduk Miskin pada kabupaten/kota di Provinsi Kalimantan Barat.

\section{Uji Koefisien Determinasi (Uji $\mathbf{R}^{2}$ )}

Nilai Adjusted R-Squared menunjukkan angka 0.963247, ini berarti bahwa setelah disesuaikan Pertumbuhan Ekonomi Jumlah Penduduk Miskin sebesar 96,32 persen, sisanya 3,68 persen dipengaruhi oleh faktor-faktor lain di luar penelitian. Faktorfaktor lain yang dapat mempengaruhi Jumlah Penduduk Miskin antara lain ketimpangan distribusi pendapatan, kepemilikan sumberdaya yang terbatas dan kualitasnya yang rendah, rendahnya kualitas sumberdaya manusia, perbedaan terhadap akses permodalan.

\section{Pengaruh Investasi Penanaman Modal Dalam Negeri Terhadap Pertumbuhan Ekonomi 10 Kabupaten/Kota Di Provinsi Kalimantan Barat}

Pengaruh positif dan signifikan investasi PMDN terhadap pertumbuhan ekonomi menunjukkan bahwa peran investasi PMDN dalam meningkatkan pertumbuhan ekonomi semakin besar, demikian juga sebaliknya. Jika dilihat rasio realisasi PMDN per sektor terhadap realisasi total PMDN Provinsi Kalimantan Barat selama periode waktu penelitiam didominasi dan tumbuh pada sektor perkebunan. Sedangkan rasio pertumbuhan PMDN di sektor-sektor lain seperti sektor industri kayu, sektor kehutanan, sektor industri kimia, industri makanan, industri kertas, industri mineral non-logam, dan industri lainnya, sektor angkutan, gudang, dan telekomunikasi, sektor perhotelan dan restoran, sektor listrik, gas \& air minum, selama periode penelitian cenderung stagnan.

Beberapa kabupaten/kota memiliki kesesuaian pola arah hubungan dengan hasil penelitian ini, yaitu daerah dengan investasi PMDN tinggi dibandingkan dengan kabupaten/kota lainnya diikuti dengan pertumbuhan ekonomi tinggi, demikian juga sebaliknya daerah dengan investasi PMDN rendah diikuti dengan pertumbuhan ekonomi yang rendah, yaitu Kabupaten Ketapang dengan rata-rata investasi PMDN tinggi selama 
periode 2008-2013 ( $\operatorname{Rp} 2.055 .297,62$ juta) dengan rata-rata pertumbuhan ekonomi tinggi (6,25\%). Demikian juga dengan Kabupaten Sintang dengan rata-rata investasi PMDN tinggi (Rp 1.673.357,69 juta) dan rata rata-rata pertumbuhan ekonomi tinggi $(5,43 \%)$. Sebaliknya, Kota Pontianak dengan rata-rata investasi PMDN rendah selama periode 2008-2013 (Rp 313.543,43 juta) dan rata-rata pertumbuhan ekonomi rendah dibanding kabupaten/kota lainnya $(4,99 \%)$.

Kecenderungan lain juga dapat dilihat dari adanya pola hubungan yang tidak searah antara investasi PMDN dengan pertumbuhan ekonomi. Beberapa kabupaten/kota dengan investasi PMDN tinggi namun pertumbuhan ekonominya rendah, yaitu Kabupaten Pontianak dengan rata-rata investasi PMDN tinggi (Rp 1.160.019,94 juta) pertumbuhan ekonominya lebih rendah dibanding kabupaten/kota lainnya $(3,26 \%)$. Kabupaten Kapuas Hulu rata-rata investasi PMDN tinggi (Rp 1.811.497,40 juta) pertumbuhan ekonominya lebih rendah dibanding kabupaten/kota lainnya $(4,47 \%)$. Sebaliknya beberapa kabupaten/kota dengan investasi PMDN rendah namun pertumbuhan ekonomi tinggi, yaitu Kabupaten Sambas dengan rata-rata investasi PMDN rendah (Rp 207.391,05 juta) namun rata-rata pertumbuhan ekonominya tinggi $(5,68 \%)$. Kabupaten Bengkayang, dengan rata-rata investasi PMDN rendah (Rp 196.864,20) dan pertumbuhan ekonomi tinggi (5,46\%). Kabupaten Landak (Rp 6.130,83) dan (5,48\%).

Hasil penelitian ini sejalan dengan teori dan penelitian terdahulu yang menjadi landasan teori dalam penelitian ini. Menurut Sitompul (2007) dalam penelitiannya mengenai analisis pengaruh investasi dan tenaga kerja terhadap PDRB Sumatera Utara menunjukkan bahwa berdasarkan investasi PMDN tahun sebelumnya berpengaruh positif terhadap PDRB Sumatera Utara. Hal ini berarti bahwa semakin meningkat investasi PMDN, maka PDRB Sumatera Utara akan semakin tinggi. Nilai koefisien regresi investasi PMDN sebesar 0,0323 berarti bahwa setiap peningkatan investasi PMDN 100\% maka menyebabkan peningkatan PDRB Sumatera Utara sebesar 3,23 persen, dengan asumsi ceteris paribus. Diketahui bahwa tingkat pertumbuhan ekonomi dan investasi mempunyai hubungan timbal balik yang positif. Hubungan timbal balik tersebut terjadi karena di satu pihak, semakin tinggi pertumbuhan ekonomi suatu negara, berarti semakin besar bagian dari pendapatan yang bisa ditabung, sehingga investasi yang tercipta akan semakin besar pula.

\section{Pengaruh Investasi PMA Terhadap Pertumbuhan Ekonomi Pada 10 Kabupaten/Kota di Provinsi Kalimantan Barat}

Pengaruh positif dan signifikan investasi PMA terhadap pertumbuhan ekonomi menunjukkan bahwa investasi PMA yang ditanamkan dalam perekonomian mampu memacu pertumbuhan ekonomi, meningkatkan peran aktif masyarakat dalam kegiatan ekonomi serta memperluas kesempatan kerja dan lapangan kerja. Realisasi PMA terhadap pertumbuhan ekonomi kabupaten/kota di Provinsi Kalimantan Barat disebabkan oleh penanaman modal asing (PMA) yang masuk ke Provinsi Kalimantan Barat 
didominasi oleh sektor perkebunan. Sektor kehutanan menunjukkan peningkatan realisasi investasi PMA yang cukup signifikan demikian juga dengan industri kayu.

Pola hubungan searah antara investasi PMA dengan pertumbuhan ekonomi ditemukan pada beberapa kabupaten, yaitu di Kabupaten Ketapang (407.840,97 US \$ dan 6,25\%), Kabupaten Sanggau (451.928,85 US \$ dan 4,95\%), dan Kabupaten Landak (172.989,23 US \$ dan 5,48\%). Selanjutnya terdapat daerah dengan investasi PMA rendah dan pertumbuhan ekonomi rendah dibanding kabuapten/ kota lainnya, yaitu Kabupaten Pontianak (77.107,27 US \$ dan 3,26\%). Pola hubungan searah ini menunjukkan pentingnya peran investasi PMA dalam memacu pertumbuhan ekonomi daerah kabupaten/kota di Provinsi Kalimantan Barat.

Hasil penelitian ini sejalan dengan penelitian Sitompul (2007) dimana investasi PMA tahun sebelumnya berpengaruh positif terhadap PDRB Sumatera Utara. Hikmatiyar, ddk (2010) dalam penelitiannya menemukan bahwa variabel PMA berpengaruh positif dan secara statistik signifikan terhadap PDRB per kapita Provinsi Jawa Tengah. Harrod-Domar (dalam Jhingan, 2000) menerangkan korelasi positif antara tingkat investasi dan laju pertumbuhan ekonomi. Alasan Harrod-Domar menetapkan investasi sebagai kunci pertumbuhan ekonomi adalah karena investasi memiliki sifat ganda menciptakan pendapatan, dan memperbesar kapasitas produksi perekonomian dengan cara meningkatkan stok modal.

Selain pola hubungan searah, dalam penelitian ini juga ditemukan beberapa kabupaten di Provinsi Kalimantan Barat dengan pola hubungan tidak searah antara investasi PMA dengan pertumbuhan ekonomi. Terdapat daerah dengan nilai realisasi investasi PMA rendah namun pertumbuhan ekonomi tinggi, yaitu di Kabupaten Sambas dengan rata-rata realisasi investasi PMA tahun 2008-2013 sebesar 81.568,05 US \$ dan laju pertumbuhan ekonomi selama periode penelitian sebesar 5,68\%, Kabupaten Bengkayang (10.938,85 US \$ dan 5,46\%), Kabupaten Sintang (43.448,78 US \$ dan 5,43\%), Kabupaten Melawi (16.109,55 US \$ dan 5,70), dan Kota Pontianak (43.247,32 US \$ dan 5,57\%).

Hasil penelitian ini tidak sejalan dengan hasil penelitian Kholis (2012) dimana berdasarkan hasil perhitungan menunjukkan bahwa Foreign Direct Investment (FDI) memberikan pengaruh negatif terhadap pertumbuhan ekonomi di Indonesia. Hal ini tidak sesuai dengan hipotesis yang menyatakan bahwa FDI akan memberikan pengaruh positif terhadap pertumbuhan ekonomi. Kondisi ini didasari oleh kenyataan bahwa investasi di Indonesia sangat fluktuatif.

\section{Pengaruh Penyerapan Tenaga Kerja Terhadap Pertumbuhan Ekonomi Pada 10 Kabupaten/Kota Di Provinsi Kalimantan Barat}

Pengaruh positif dan signifikan penyerapan tenaga kerja terhadap pertumbuhan ekonomi menunjukkan bahwa semakin banyak tenaga kerja terserap, demikian juga sebaliknya. Seperti yang kita ketahui bahwa ekspansi besar-besaran pada perkebunan 
kelapa sawit berdampak pada semakin banyaknya penyerapan tenaga kerja di sektor ini. Perkebunan kelapa sawit tidak hanya dimiliki oleh perkebunan besar (corporate), namun juga diusahakan dan dimiliki oleh rakyat (perkebunan rakyat). Hal ini sejalan dengan hasil penelitian Wiwin mengenai "Perkebunan Kelapa Sawit dan Kesejahteraan Masyarakat di Kabupaten Sambas" menunjukkan bahwa kegiatan pembangunan perkebunan telah menimbulkan mobilitas penduduk yang tinggi. Akibatnya di daerahdaerah sekitar pembangunan perkebunan muncul pusat-pusat pertumbuhan ekonomi di pedesaan. Kondisi ini menyebabkan meningkatnya daya beli masyarakat pedesaan, terutama terhadap kebutuhan rutin rumah tangga dan kebutuhan sarana produksi perkebunan kelapa sawit. Perputaran uang yang terjadi di lokasi dalam jangka panjang diperkirakan dapat merangsang pertumbuhan ekonomi di wilayah ini dengan tumbuhnya perdagangan dan jasa. Hal ini memberikan arti bahwa kegiatan perkebunan kelapa sawit di pedesaan menciptakan multiplier effect, terutama dalam lapangan pekerjaan dan peluang berusaha.

Beberapa kabupaten menunjukkan kesesuaian pola hubungan searah antara penyerapan tenaga kerja dengan pertumbuhan ekonomi, dimana penyerapan tenaga kerja tinggi dan pertumbuhan ekonomi tinggi yaitu pada Kabupaten Sambas (216.230,29 jiwa dan 5,68\%), Kabupaten Landak (134.736,14 jiwa dan 5,48\%), Kabupaten Ketapang (173.398,00 jiwa dan 6,25\%), Kabupaten Sintang dan (165.032,71 jiwa dan 5,43\%). Terdapat juga daerah dengan penyerapan tenaga kerja rendah dan pertumbuhan ekonomi rendah yaitu pada Kabupaten Pontianak (86.727,71 jiwa dan 3,26\%).

Sebaliknya, pola hubungan tidak searah juga ditemukan pada beberapa kabupaten/kota dimana penyerapan tenaga kerja tinggi namun pertumbuhan ekonomi rendah, yaitu pada Kabupaten Kapuas Hulu (101.284,43 jiwa dan 4,47\%) dan Kota Pontianak (196.677,57 jiwa dan 4,99\%). Terdapat juga daerah dengan penyerapan tenaga kerja rendah namun pertumbuhan ekonominya tinggi yaitu pada Kabupaten Bengkayang (87.806,57 jiwa dan 5,46\%).

Hal ini sejalan dengan hasil penelitian Mariana dkk (2014) mengenai, Pengaruh Investasi, Pertumbuhan Penyerapan Tenaga Kerja Terhadap Pertumbuhan Ekonomi dan Perubahan Struktur Ekonomi di Provinsi Bali. berdasarkan hasil penelitian diketahui bahwa pertumbuhan penyerapan tenaga kerja memiliki pengaruh langsung yang positif dan signifikan terhadap pertumbuhan ekonomi. Sebagaimana pengertian bahwa pertumbuhan ekonomi adalah perubahan PDRB antara tahun bersangkutan dengan tahun sebelumnya. Jelas dapat disimpulkan bahwa dengan bertambahnya pertumbuhan penyerapan tenaga kerja tentunya akan menghasilkan peningkatan atas PDRB juga, demikian sebaliknya.

Kajian empiris lainnya yang dilakukan oleh Datrini (2009) mengenai dampak investasi dan tenaga kerja terhadap pertumbuhan ekonomi serta pengaruhnya terhadap tingkat kemiskinan di Provinsi Bali selama kurun waktu 1990-2007 menunjukkan bahwa secara parsial investasi tidak berpengaruh, tetapi sebaliknya tenaga kerja berpengaruh 
positif dan signifikan terhadap pertumbuhan ekonomi Provinsi Bali periode tahun 19902007. Berdasarkan analisis elastisitas ditemukan bahwa pertumbuhan ekonomi tidak peka akibat adanya perubahan investasi, namun peka terhadap perubahan jumlah penyerapan tenaga kerja.

\section{Pengaruh Pertumbuhan Ekonomi Terhadap Jumlah Penduduk Miskin 10 Kabupaten/Kota Di Provinsi Kalimantan Barat}

Pola hubungan tidak searah antara pertumbuhan ekonomi terhadap jumlah pendududk miskin ditemukan pada beberapa kabupaten/kota. Pertumbuhan ekonomi tinggi dan jumlah penduduk miskin rendah pada Kabupaten Bengkayang (5,46\% dan 17.630, 50 jiwa), dan Kabupaten Melawi (5,70\% dan 24.660,50 jiwa). Sementara itu, tidak ditemukan kabupaten/kota dengan pertumbuhan ekonomi rendah dan jumlah penduduk miskin tinggi.

Pola hubungan searah antara pertumbuhan ekonomi dengan jumlah penduduk miskin juga ditemukan dalam penelitian ini, dimana pertumbuhan ekonomi tinggi dan jumlah penduduk miskin juga tinggi, yaitu pada Kabupaten Sambas (5,68\% dan $51.749,33$ jiwa), Kabupaten Landak (5,48\% dan 50.863,50 jiwa), Kabupaten Ketapang (6,25\% dan 59.087,67 jiwa), dan Kabupaten Sintang (5,43\% dan 40.376,00 jiwa). Sebaliknya, terdapat daerah dengan pertumbuhan ekonomi rendah dan jumlah penduduk miskin juga rendah yaitu di Kabupaten Pontianak (3,26\% dan 14.606,83 jiwa), Kota Pontianak (4,99\% dan 37.933,83 jiwa), Kabupaten Kapuas Hulu (4,47\% dan 25.112,17 jiwa) dan Kabupaten Sanggau (4,95\% dan 20.971 jiwa).

Hasil penelitian ini sejalan dengan penelitian yang dilakukan oleh Sumarto (2002) dari SMERU yang menyimpulkan bahwa terdapat hubungan negatif antara pertumbuhan ekonomi dengan kemiskinan. Siregar dan Wahyuniarti (2008) yang menyimpulkan bahwa peningkatan PDRB sebesar 1 unit akan menurunkan kemiskinan sebesar 0,009 unit, ceteris paribus. Artinya setiap kenaikan PDRB sebesar Rp 1 triliun akan mengurangi atau menurunkan jumlah penduduk miskin sekitar 9000 orang. Hal ini menunjukkan pentingnya mempercepat pertumbuhan ekonomi untuk menurunkan jumlah penduduk miskin. Pertumbuhan ekonomi terbukti memberikan dampak terhadap berkurangnya jumlah penduduk.

Hasil penelitian Nizar (2013) mengenai pengaruh investasi dan tenaga kerja terhadap pertumbuhan ekonomi serta hubungannya terhadap tingkat kemiskinan di Indonesia, mendukung penelitian Nizar. Data yang digunakan adalah data time series tahun 1980-2010. Hasil penelitian ini menunjukkan bahwa pengaruh pertumbuhan ekonomi (PDB) terhadap tingkat kemiskinan secara langsung sangat kecil namun hubungannya negatif dan signifikan. Artinya jika terjadi perubahan pertumbuhan ekonomi (GDP) sebesar 1 unit maka akan menurunkan persentase kemiskinan sebesar $0,000361 \%$ dengan asumsi faktor lain tetap. Terlihat bahwa pengaruh pertumbuhan 
ekonomi terhadap pengurangan kemiskinan sangat kecil sekali. Dengan asumsi derajat kepercayaan $10 \%$ maka pengaruh variabel bebas adalah signifikan terhadap variabel terikat.

Dalam penelitian ini juga ditemukan kabupaten dengan kondisi yang bertentangan dengan teori dimana pertumbuhan ekonomi tinggi dan jumlah penduduk juga tinggi. Pertumbuhan Produk Domestik Regional Bruto (PDRB) Kabupaten Ketapang atas harga konstan Kabupaten Ketapang tahun 2010 tercatat sebesar 7,51 persen. Pertumbuhan ini lebih tinggi dibanding pertumbuhan ekonomi Provinsi Kalimantan Barat sebesar 5,35 persen. Bahkan merupakan pertumbuhan tertinggi di antara kabupaten/kota se-Provinsi Kalimantan Barat, namun rata-rata jumlah penduduk miskin di kabupaten ini selama periode waktu penelitian juga yang tertinggi.

Hal ini juga menunjukkan bahwa pertumbuhan ekonomi tidak dinikmati secara merata oleh anggota masyarakat dengan ketimpangan yang tinggi. Pertumbuhan ekonomi hanya dinikmati oleh kelompok masyarakat yang kaya. Hal ini akan berdampak pada berkurangnya keefektifan pertumbuhan ekonomi untuk mengentaskan kemiskinan. Penelitian Datrini (2009) mengenai dampak investasi dan tenaga kerja terhadap pertumbuhan ekonomi serta pengaruhnya terhadap tingkat kemiskinan di Provinsi Bali selama kurun waktu 1990-2007 ternyata menemukan bahwa tidak ada pengaruh yang signifikan pertumbuhan ekonomi terhadap tingkat kemiskinan meskipun hubungannya negatif. Peningkatan atau pengurangan jumlah penduduk miskin tidak peka akibat pertumbuhan PDRB Provinsi Bali pada periode 1990-2007.

Beberapa kecenderungan menunjukkan bahwa kenaikan pertumbuhan ekonomi tidak memberikan dampak yang signifikan terhadap perbaikan taraf hidup masyarakat miskin juga dijelaskan oleh berbagai literatur dan hasil penelitian. Faisal Basri dan Haris Munandar (2006) dan Ahmad Erani Yustika (2010) misalnya memasukkan masalah ini menjadi salah satu masalah struktural dalam perekonomian Indonesia yang selama ini tidak disadari oleh pemerintah dan merupakan ancaman yang berbahaya bagi perekonomian Indonesia. Mereka mengemukakan bahwa kualitas pertumbuhan ekonomi Indonesia belum bisa menekan angka kemiskinan, karena yang menjadi leading sektor dalam pertumbuhan ekonomi tersebut adalah sektor non tradable yang padat modal. Sektor tersier (non tradable) yang memberikan kontrbusi besar dalam pertumbuhan ekonomi ternyata hanya mampu menyerap sedikit dari sekian banyak tenaga kerja yang ada di Indonesia. Pencari kerja yang terus meningkat simultan dengan pertumbuhan ekonomi yang mengalami ketimpangan. Secara perlahan namun konsisten, sektor industri dan jasa mulai menggantikan peran sektor pertanian dalam pertumbuhan ekonomi kabupaten/kota di Provinsi Kalimantan Barat.

Sumarno (2002) dalam Kuncoro (2004), menemukan bahwa terdapat hubungan positif dan signifikan secara langsung dengan pertumbuhan ekonomi terhadap kemiskinan di Sulawesi Selatan. Artinya, ketika perekonomian tumbuh, kemiskinan 
berkurang, namun ketika perekonomian mengalami kontraksi pertumbuhan, kemiskinan meningkat lagi.

Tingkat kemiskinan sebagai salah satu indikator pembangunan menunjukkan pola hubungan yang berbeda-beda dengan indikator pembangunan lainnya, seperti total output wilayah yang diukur dalam Produk Domestik Regional Bruto (PDRB). Kabupaten Ketapang sebagai salah satu wilayah berbasis sektor pertanian dan penyumbang ketiga terbesar total PDRB provinsi, jumlah penduduk miskinnya adalah yang tertinggi di Provinsi Kalimantan Barat. Demikian halnya dengan Kota Pontianak dengan basis ekonomi daerah adalah sektor sekunder dan tersier, juga menunjukkan jumlah penduduk miskin tertinggi keempat di provinsi ini. Keterkaitan antara pola aktivitas ekonomi dengan kemiskinan berbeda antar satu daerah dengan daerah lainnya. Oleh karena itu program pembangunan tidak boleh hanya diukur melalui peningkatan pendapatan perkapita yang semakin meningkat, tetapi harus memperhatikan sejauh mana distribusi pendapatan telah menyebar ke lapisan masyarakat serta siapa yang telah menikmati hasil-hasilnya.

\section{SIMPULAN}

Nilai konstanta sebesar -19,001, artinya apabila variabel PMDN, PMA, dan Penyerapan Tenaga Kerja tidak mengalami perubahan, maka Pertumbuhan Ekonomi kabupaten/kota di Provinsi Kalimantan Barat sebesar -19,001 persen. Investasi PMDN berpengaruh positif dan signifikan terhadap pertumbuhan ekonomi kabupaten/kota di Provinsi Kalimantan Barat dengan nilai koefisien sebesar 0,053. Peningkatan investasi PMDN akan meningkatkan pertumbuhan ekonomi secara signifikan.

Investasi PMA berpengaruh positif dan signifikan terhadap pertumbuhan ekonomi kabupaten/kota di Provinsi Kalimantan Barat dengan nilai koefisien sebesar 0,415. Peningkatan investasi PMA akan meningkatkan pertumbuhan ekonomi secara signifikan. Penyerapan tenaga kerja berpengaruh positif dan signifikan terhadap pertumbuhan ekonomi kabupaten/kota di Provinsi Kalimantan Barat dengan nilai koefisien sebesar 1,602. Peningkatan penyerapan tenaga kerja akan meningkatkan pertumbuhan ekonomi secara signifikan. Pertumbuhan ekonomi berpengaruh negatif dan signifikan terhadap jumlah penduduk miskin kabupaten/kota di Provinsi Kalimantan Barat dengan nilai koefisien sebesar -0,051. Peningkatan pertumbuhan ekonomi akan menurunkan atau mengurangi jumlah penduduk miskin secara signifikan.

Berdasarkan hasil penelitian diketahui bahwa investasi PMDN, PMA dan penyerapan tenaga kerja berpengaruh positif dan signifikan terhadap pertumbuhan ekonomi. Investasi memberikan dampak yang baik bagi penyerapan tenaga kerja terutama pada sektor perkebunan. Penyerapan tenaga kerja yang cukup besar di sektor ini perlu didukung oleh pemerintah melalui berbagai kebijakan yang lebih berpihak kepada petani, diharapkan melalui berbagai kebijakan dan keberpihakan kepada petani maka 
produktifitas petani juga akan meningkat, pada akhirnya kemiskinan yang identik dengan keluarga petani dapat dikurangi.

Pertumbuhan ekonomi berpengaruh negatif dan signifikan terhadap jumlah penduduk miskin pada 10 kabupaten/kota di Kalimantan Barat. Hal ini menunjukkan bahwa kenaikan pertumbuhan ekonomi mampu mengurangi jumlah penduduk miskin secara signifikan. Para pembuat kebijakan diharapkan tidak hanya menekankan aspek kuantitas dari pertumbuhan ekonomi, namun yang terpenting adalah memberikan perhatian yang lebih pada struktur dan kualitas dari pertumbuhan ekonomi itu sendiri. Memetakan potensi kabupaten/kota sesuai dengan potensi dan karakteristiknya, sehingga PMDN dan PMA yang masuk ke Kalimantan Barat kedepannya lebih maksimal dan pada akhirnya dapat memberikan dampak positif terhadap pertumbuhan ekonomi masing-masing kabupaten/kota khususnya dan pertumbuhan ekonomi Provinsi Kalimantan Barat

\section{DAFTAR PUSTAKA}

Agussalim. (2009). Mereduksi kemiskinan : Sebuah Proposal Baru Untuk Indonesia. Makassar : Nala Cipta Litera.

Arsyad, L. (1999). Ekonomi Pembangunan. Edisi Keempat. Yogyakarta: STIE YKPN.

Badan Pusat Statistik. (2013). Data dan Informasi Kemiskinan Kabupaten/Kota. Pontianak: BPS Provinsi Kalimantan Barat.

Badan Pusat Statistik. (2013). Kalbar Dalam Angka 2008-2013. Pontianak: BPS Provinsi Kalimantan Barat.

Badan Pusat Statistik. (2013). Statistik Ketenagakerjaan Kalimantan Barat. Pontianak: BPS Provinsi Kalimantan Barat.

Basri, F., \& Munandar, H. (2009). Lanskap ekonomi Indonesia : Kajian dan Renungan Terhadap Masalah-Masalah Struktural, Transformasi Baru, dan Prospek Perekonomian Indonesia. Jakarta : Penerbit Kencana.

Datrini, L. K. (2009). Dampak Investasi dan Tenaga Kerja Terhadap Pertumbuhan Ekonomi Serta Pengaruhnya terhadap tingkat kemiskinan di Provinsi Bali. Jurnal Sarathi. Vol. 16 (3).

Hasan, E., Amar, S., Anis, A. (2013). Pengaruh Investasi, Angkatan Kerja, dan Pengeluaran Pemerintah Terhadap Pertumbuhan Ekonomi di Provinsi Sumatera Barat. Jurnal Riset Manajemen Bisnis dan Publik. Vol. 1 (1).

Hermawan, A. (2009). Penelitian Bisnis Paradigma Kuantitatif. Jakarta: Grasindo. 
Hidayat, S., \& Panturu, A. A (2007). Pertumbuhan Ekonomi, Ketidakmerataan Pendapatan dan Kemiskinan: Estimasi Parameter Elastisitas Kemiskinan Tingkat Provinsi Di Indonesia Tahun 1996-2005. Jakarta : Universitas Indonesia.

Hikmatiyar, P. F., \& Hayati, B. (2011). Analisis Pengaruh PMDN, PMA, dan Jumlah Angkatan Kerja Terhadap PDRB Per Kapota Provinsi Jawa Tengah Tahun 1995-2009. Fakultas Ekonomi Universitas Diponegoro Semarang.

Jhingan, M. L. (2008). Ekonomi Pembangunan dan Perencanaan. Jakarta: PT. Raja Grafindo Persada.

Kakwani, N., \& Pernia, E, M. (2000). What is pro-poor growth? Asian Development Review. Vol. 18 (1).

Kholis, M. (2012). Dampak Foreign Direct Investment Terhadap Pertumbuhan Ekonomi Indonesia. Jurnal Organisasi dan Manajemen. Vol. 8 (2) : pp 111-120.

Kuncoro, M. (2004). Otonomi dan Pembangunan Daerah: Reformasi, Perencanaan, Strategi, dan Peluang. Jakarta : Erlangga.

Kuncoro, M. (2006). Ekonomika Pembangunan: Teori, Masalah, dan Kebijakan. Yogyakarta: UPP STIM YKPN.

Kuncoro, M. (2007). Metode Kuantitatif: Teori dan Aplikasi Untuk Bisnis dan Ekonomi, Edisi Ketiga. Yogyakarta: UPP STIM YKPN.

Mankiw, N. G. (2007). Makroekonomi. Edisi Keenam. Jakarta: Erlangga.

Mawardi, I. (2012). Pengaruh Investasi Dan Tenaga Kerja Terhadap Pertumbuhan Ekonomi Serta Dampaknya Terhadap Tingkat Kemiskinan Di Indonesia Tahun 1980-2010. Fakultas Ekonomi Universitas Pembangunan Nasional "Veteran" Yogyakarta.

Momongan, J. E. (2013). Investasi PMA dan PMDN Terhadap Perkembangan PDRB dan Penyerapan Tenaga Kerja Serta Penanggulangan Kemiskinan di Sulawesi Utara. Jurnal EMBA. Vol.1 (3): pp 530-539.

Monoarfa, M. A (2009). Good Governance Dalam Tinjauan Otonomi Daerah. Fakultas Ekonomi dan Bisnis Universitas Negeri Gorontalo.

Nizar, C., Hamzah, A., \& Syahnur, S. (2013). Pengaruh Investasi dan Tenaga Kerja Terhadap Pertumbuhan Ekonomi Serta Hubungannya Terhadap Tingkat Kemiskinan di Indonesia. Jurnal Ilmu Ekonomi Pascasarjana Universitas Syiah Kuala. Vol 1 (2): pp 1-8. 
Novena, M., Utama, M. S., \& Purbadharmaja, I. B (2014). Pengaruh Pertumbuhan Investasi, Pertumbuhan Penyerapan Tenaga Kerja terhadap Pertumbuhan Ekonomi dan Perubahan Struktur Ekonomi di Provinsi Bali. E-Jurnal Ekonomi dan Bisnis Universitas Udayana. Vol. 3.(6) : pp 330-344.

Rahardja, P., \& Manurung, M. (2008). Pengantar Ilmu Ekonomi dan Makroekonomi. Jakarta: Lembaga Penerbit FEUI.

Rusdarti., \& Sebayang, L. K. (2013). Faktor- Faktor Yang Mempengaruhi Tingkat Kemiskinan di Provinsi Jawa Tengah. Jurnal Economia. Vol. 9 (1).

Rustiono, D. (2008). Analisis Pengaruh Investasi, Tenaga Kerja, dan Pengeluaran Pemerintah Terhadap Pertumbuhan Ekonomi di Propinsi Jawa Tengah. Semarang: Magister Ilmu Ekonomi Universitas Diponegoro.

Silalahi, U. (2009). Metode Penelitian Sosial. Bandung: PT. Refika Aditama.

Siregar, H., \& Winarti, Dwi Wahyu. (2008). Dampak Pertumbuhan Ekonomi Terhadap Penurunan Jumlah Penduduk Miskin.

Sitompul, N. L. 2007. Analisis Pengaruh Investasi dan Tenaga Kerja Terhadap PDRB Sumatera Utara. USU e-Repository.

Sukirno, S. (2010). Makroekonomi, Teori Pengantar. Edisi Ketiga. Jakarta: PT. RajaGrafindo Persada.

Sumarto, A. H. (2010). Jurus Mabuk Membangun Ekonomi Rakyat. Jakarta: PT. Indeks.

Todaro, M. P., \& Smith, S. (2000). Pembangunan Ekonomi di Dunia Ketiga. Edisi Ketujuh. Jakarta: Bumi Aksara.

Todaro, M. P., \& Smith, S. (2006). Pembangunan Ekonomi. Edisi Kesembilan. Jakarta: Erlangga.

Wiradyatmika, A. A. G. A., \& Sudiana, I. K. (2013). Pengaruh Jumlah Penduduk, Jumlah Penyerapan Tenaga Kerja dan Pengangguran Terhadap Jumlah Penduduk Miskin di Kabupaten Buleleng. E-Jurnal Ekonomi Pembangunan Universitas Udayana. Vol. 2 (7): pp 314-349.

Yacoub, Y. (2012). Pengaruh Tingkat Pengangguran Terhadap Tingkat Kemiskinan Kabupaten/Kota di Provinsi Kalimantan Barat. Jurnal EKSOS. Vol. 8 (3): pp $176-185$. 